\title{
HUBUNGAN DUKUNGAN KELUARGA DENGAN KUALITAS HIDUP PASIEN PASCA STROKE DI WILAYAH KERJA PUSKESMAS BANJARSARI METRO
}

\author{
CORRELATION OF FAMILY SUPPORT WITH LIFE QUALITY \\ POST STROKE PATIENTS IN THE WORKING AREA HEALTH CENTER \\ BANJARSARI METRO
}

\author{
Ludiana $^{1}$, Supardi $^{2}$ \\ 1,2Akademi Keperawatan Dharma Wacana Metro \\ e-mail: ludy73.ana@gmail.com
}

\begin{abstract}
ABSTRAK
Stroke merupakan penyakit kronis yang mengenai sistem saraf, penyakit ini memiliki problematika pasca stroke yang dapat menurunkan kualitas hidup bagi penderita. Keluarga merupakan orang terdekat yang memiliki peranan penting dalam merawat penderita stroke. Tujuan penelitian ini adalah untuk mengetahui hubungan dukungan keluarga terhadap Kualitas Hidup Pasien Pasca Stroke di Wilayah Kerja Puskesmas Banjarsari Metro tahun 2018. Jenis penelitian analitik, rancangan cross sectional. Populasi dalam penelitian ini adalah pasien pasca stroke yang tercatat pada tahun 2018 yaitu sebanyak 27 orang, teknik pengambilan sampel total sampling. Analisis menggunakan uji Person product moment. Hasil: Rata-rata dukungan keluarga pada pasien pasca stroke adalah 70,63 $\pm 2,483$ dan rata-rata kualitas hidup pasien pasca stroke adalah $120,04 \pm 4,328$. Hasil analisis didapatkan $r=0,774 ; p$-value $0,000<\alpha 0,05$ artinya ada hubungan antara dukungan keluarga dengan kualitas hidup pasien pasca stroke. Nilai korelasi yang didapatkan termasuk dalam kategori kuat dengan arah korelasi positif. Kesimpulan: Dukungan keluarga terbukti memiliki hubungan kuat terhadap kualitas hidup pasien pasca stroke. Diharapkan keluarga terus berupaya memberikan dukungan secara maksimal agar kualitas hidup pasien pasca stroke mengalami peningkatan.
\end{abstract}

Kata Kunci : Dukungan keluarga, kualitas hidup pasien pasca stroke.

\begin{abstract}
Stroke is a chronic disease affecting the nervous system, this disease has post-stroke problems that can reduce the quality of life for sufferers. The family is the closest person who has an important role in treating stroke patients. The purpose of this study was to determine the relationship of family support to the Quality of Life for Post-Stroke Patients in the Work Area of Banjarsari Metro Health Center in 2018. Methods: Type of analytic research, cross sectional design. The population in this study were post-stroke patients recorded in 2018 as many as 27 people, total sampling technique. The analysis uses the Person product moment test. Results: The average family support for post-stroke patients is $70.63 \pm 2.483$ and the average quality of life for post-stroke patients is $120.04 \pm 4.328$. The analysis results obtained $r=0.774$; $p$-value $0,000<0,05$ means that there is a relationship between family support and the quality of life of post-stroke patients. The correlation value obtained is included in the strong category with a positive correlation direction. Conclusion: Family support has been shown to have a strong relationship to the quality of life of post-stroke patients. It is expected that families continue to strive to provide maximum support so that the quality of life of post-stroke patients increases.
\end{abstract}

Keywords : Family support, quality of life for post-stroke patients. 


\section{PENDAHULUAN}

Gaya hidup tidak sehat saat ini telah banyak menimbulkan masalah kesehatan di masyarakat terutama pada gangguan sistem kardiovaskuler. Penyakit kardiovaskuler merupakan penyebab utama kematian di dunia yang banyak disebabkan oleh gaya hidup kurang sehat. Setiap tahunnya diperkirakan terjadi 17,5 juta orang meninggal karena penyakit ini yang mewakili $31 \%$ dari seluruh kematian secara global. Dari jumlah kematian tersebut, 7,4 juta diantaranya disebabkan penyakit jantung koroner dan 6,7 juta karena stroke'. Stroke merupakan istilah yang digunakan untuk menggambarkan perubahan neurologis yang disebabkan oleh adanya gangguan suplai darah ke bagian dari otak. Jenis stroke yang utama adalah iskemik dan hemoragik. Jumlah total stroke iskemik sekitar $83 \%$ dari seluruh kasus stroke. Sisanya sebesar $17 \%$ adalah stroke hemoragik. Di Amerika Serikat sekitar 550.000 orang mengalami stroke setiap tahun. Ketika stroke yang kedua kalinya dimasukkan dalam kondisi tersebut, angka kejadian meningkat menjadi 700.000 per tahun ${ }^{2}$.

Angka kejadian stroke di Indonesia juga cenderung mengalami peningkatan, pada hasil Riskesdas 2007 insiden stroke di Indonesia adalah 8,3 per 1.000 penduduk, dan pada hasil Riskesdas 2013 mengalami peningkatan yaitu menjadi 12,1 per 1.000 penduduk dan merupakan penyebab kematian utama hampir di semua rumah sakit di Indonesia yakni mencapai $14,5 \%$. Jumlah penderita penyakit stroke di Indonesia tahun 2013 berdasarkan diagnosis tenaga kesehatan (Nakes) diperkirakan sebanyak 1.236 .825 orang $(7,0 \%)$, sedangkan berdasarkan diagnosis Nakes/gejala diperkirakan sebanyak 2.137.941 orang $(12,1 \%)$. Angka kejadian stroke Provinsi Lampung tergolong tinggi dari diagnosa tenaga kesehatan (Nakes) yaitu diperkirakan mencapai 42.815 dan pada diagnosis Nakes/gejala 68.393. Prevalensi stroke berdasarkan diagnosa/gejala tiga besar tertinggi adalah kabupaten Waykanan dan Lampung Tengah masing-masing 0.9\%, dan terendah kabupaten Tulangbawang sebesar $0.2 \%$ sedangkan untuk wilayah Kota Metro adalah sebesar $0,5 \%{ }^{3}$.

Berdasarkan data yang tercatat di Kasie Surveilans \& Epidemiologi Dinas Kesehatan Kota Metro menunjukkan bahwa jumlah penderita stroke mencapai 482 kasus sedangkan pada laporan terakhir 2016 jumlah kasus baru stroke ditemukan sebanyak 70 kasus. Untuk Wilayah Kerja Puskesmas Banjarsari sebanyak 27 kasus 9 .

Peningkatan angka kejadian stroke saat ini dapat dipengaruhi oleh berbagai faktor diantaranya adalah hipertensi, obesitas, kolesterol darah tinggi, adanya riwayat penyakit jantung, diabetes mellitus, gaya hidup tidak sehat seperti perilaku merokok dan stress ${ }^{4}$. Selain faktor tersebut, faktor usia juga merupakan faktor utama yaitu semakin meningkatnya usia maka risiko stroke semakin meningkat dan stroke juga banyak ditemukan pada pria dibandingkan pada wanita ${ }^{5}$.

Sebagai penyakit kronis yang mengenai sistem saraf, maka penyakit ini memiliki problematika pasca stroke seperti kelumpuhan pada salah satu 
sisi tubuh (hemiparese/hemiplegia), lumpuh pada salah satu sisi wajah, tonus otot lemah atau kaku, menurun/hilangnya rasa, gangguan lapang pandang, gangguan bahasa, gangguan persepsi dan gangguan status mental, termasuk gangguan kognitif dan fungsi memori. Sebagian besar pasien pasca stroke akan mengalami tanda-tanda ini sebagai gelaja sisa pasca stroke. Terakumulasinya berbagai gejala sisa pasca stroke, baik fisik maupun psikis ini akan mengakibatkan problematika yang lebih luas. Problematika ini antara lain problematika ketidakmampuan fungsi dasar, ketidakmampuan dalam beraktifitas sehari-hari, ketidakmampuan bersosialisasi, kemunduran fungsi kognitif sampai dengan problematika psikologis. Demikian pula akibat lanjut problematika pasca stroke adalah ketidakmandirian pasien yang akan menjadikan kualitas hidup pasien pasca stroke rendah ${ }^{6}$.

Kualitas hidup pada pasien stroke dianggap sebagai salah satu cara yang paling penting untuk mengukur outcome stroke, tetapi hanya sedikit perhatian yang diberikan pada penelitian tentang kualitas hidup ${ }^{7}$. Kualitas hidup penderita pasca stroke dapat mengalami gangguan atau hambatan. Oleh karena itu dukungan sosial keluarga juga berperan dalam meningkatkan kualitas hidup penderita pasca stroke ${ }^{8}$.

Dukungan sosial keluarga adalah sumber daya eksternal utama. Sifat dukungan sosial dan pengaruhnya pada penyelesaian masalah telah diteliti secara ekstensif dan telah terbukti sebagai moderator stres kehidupan yang efektif. Dukungan sosial keluarga dapat membuat orang percaya bahwa dirinya diperhatikan atau dicintai, dukungan keluarga juga menyebabkan seseorang merasa bahwa dirinya dianggap atau dihargai. Selain itu, dukungan keluarga juga membuat seseorang merasa bahwa dirinya merupakan bagian dari jaringan komunikasi dan saling ketergantungan.

Berdasarkan uraian di atas, maka penulis tertarik untuk melakukan penelitian tentang hubungan dukungan keluarga terhadap Kualitas Hidup Pasien Pasca Stroke di Wilayah Kerja Puskesmas Banjarsari Metro.

\section{METODE}

Jenis penelitian ini analitik menggunakan desain cross sectional. Populasi dalam penelitian ini adalah pasien pasca stroke di Wilayah Kerja Puskesmas Banjarsari Metro yang berjumlah 27 orang dan seluruhnya dijadikan sampel (total sampling). Pengumpulan data untuk mengukur kualitas hidup dilakukan menggunakan stroke specific quality of life scale (SSQOL) dan untuk mengukur dukungan keluarga menggunakan kuesioner.

\section{HASIL}

Berdasarkan pengumpulan dan analisis data maka didapatkan hasil penelitian sebagai berikut.

Tabel 1

Distribusi Usia Pasien Pasca Stroke di Wilayah Kerja Puskesmas Banjarsari Metro

\begin{tabular}{lccccc}
\hline Variabel & $\boldsymbol{N}$ & Mean & SD & $\begin{array}{c}\text { Min- } \\
\text { Max }\end{array}$ & CI;95\% \\
\hline Usia & 27 & 60,59 & 7,792 & $43-79$ & $\begin{array}{c}57,51- \\
63,67\end{array}$ \\
\hline
\end{tabular}


Berdasarkan tabel 1, dapat dijelaskan bahwa rata-rata usia pasien pasca stroke adalah $60,59 \pm 7,792$ tahun dengan usia termuda 43 tahun dan usia paling tua adalah 79 tahun.

Tabel 2

Distribusi Karakteristik Pasien Pasca Stroke Berdasarkan Jenis Kelamin, Pendidikan \& Pekerjaan di Wilayah Kerja Puskesmas Banjarsari Metro

\begin{tabular}{|c|c|c|}
\hline Variabel & $\mathbf{F}$ & Peresentase (\%) \\
\hline \multicolumn{3}{|l|}{ Jenis Kelamin } \\
\hline Laki-laki & 13 & 48,1 \\
\hline Perempuan & 14 & 51,9 \\
\hline Jumlah & 27 & 100 \\
\hline \multicolumn{3}{|l|}{ Pendidikan } \\
\hline SD & 17 & 63,0 \\
\hline SMP & 4 & 22,2 \\
\hline \multirow[t]{2}{*}{ SMA } & 6 & 14,8 \\
\hline & 27 & 100 \\
\hline \multicolumn{3}{|l|}{ Pekerjaan } \\
\hline IRT & 14 & 51,9 \\
\hline Tani & 6 & 22,2 \\
\hline Wiraswasta & 7 & 25,9 \\
\hline Jumlah & 27 & 100 \\
\hline
\end{tabular}

Berdasarkan tabel 2, dapat dijelaskan bahwa dilihat dari jenis kelamin, sebagian besar pasien pasca stroke adalah perempuan yaitu sebanyak 14 orang $(51,9 \%)$ dan laki-laki 13 orang $(48,1 \%)$. Dilihat dari tingkat pendidikan sebagian besar adalah lulusan SD yaitu sebanyak 17 orang $(63,0 \%)$, SMA 6 orang $(17,8 \%)$ dan SMP 4 orang $(22,2 \%)$. Adapun pekerjaan. Sedangkan dilihat dari pekerjaan sebagian besar adalah IRT yaitu sebanyak 14 orang $(51,9 \%)$, wiraswasta 7 orang $(25,9 \%)$ dan tani 6 orang $(22,2 \%)$.

Tabel 3

Distribusi Dukungan Keluarga dan Kualitas Hidup Pasien Pasca Stroke di Wilayah Kerja Puskesmas Banjarsari Metro

\begin{tabular}{ccccc}
\hline Variabel & Mean & SD & $\begin{array}{c}\text { Minimum- } \\
\text { Maksimum }\end{array}$ & $\begin{array}{c}\text { CI; } \\
\mathbf{9 5 \%}\end{array}$ \\
\hline $\begin{array}{c}\text { Dukungan } \\
\text { keluarga }\end{array}$ & 70,63 & 2,483 & $64-75$ & $\begin{array}{c}69,65- \\
71,61\end{array}$ \\
\hline $\begin{array}{c}\text { QOL Pasca } \\
\text { Stroke }\end{array}$ & 120,04 & 4,328 & $110-127$ & $\begin{array}{c}118,33- \\
121,75\end{array}$ \\
\hline
\end{tabular}

Berdasarkan tabel 3, dapat dijelaskan bahwa skor rata-rata dukungan keluarga pada pasien pasca stroke adalah $70,63 \pm 2,483$. Skor tertinggi dukungan keluarga adalah 75 dan skor terendah 64. Sedangkan rata-rata skor kualitas hidup pasien pasca stroke adalah $120,04 \pm 4,328$. Skor tertinggi kualitas hidup pasien pasca stroke adalah 127 dan skor terendah 110 .

\section{Tabel 4}

Hubungan Dukungan Keluarga dengan Kualitas Hidup Pasien Pasca Stroke di Wilayah Kerja Puskesmas Banjarsari Metro

\begin{tabular}{lcccccc}
\multicolumn{1}{c}{ Variabel } & Mean & $\boldsymbol{S D}$ & $\boldsymbol{p}$-value & $\boldsymbol{r}$ & $\boldsymbol{N}$ \\
\cline { 1 - 3 } $\begin{array}{l}\text { Dukungan } \\
\text { Keluarga }\end{array}$ & 70,63 & 2,483 & & & \\
$\begin{array}{l}\text { QOL Pasca } \\
\text { stroke }\end{array}$ & 120,04 & 4,328 & & & \\
\hline
\end{tabular}

Berdasarkan tabel 4, dapat diketahui bahwa pada hasil analisis dengan menggunakan korelasi Person Product Moment diperoleh rata-rata dukungan keluarga pada pasien pasca stroke adalah $70,63 \pm 2,483$ dan rata-rata skor kualitas hidup adalah 120,04 $\pm 4,328$. Pada hasil uji statistik didapatkan nilai $p$-value $=0,000$ $(p<\alpha 0,05)$ yang menunjukkan ada hubungan antara dukungan keluarga dengan kualitas hidup pasien pasca stroke. Hasil korelasi Pearson didapatkan nilai sebesar 0,774 arah korelasi positif dengan kekuatan hubungan kuat, artinya semakin tinggi dukungan keluarga maka akan semakin meningkatkan kualitas hidup pasien pasien pasca stroke.

\section{PEMBAHASAN}

Distribusi Dukungan Keluarga pada Pasien Pasca Stroke

Hasil penelitian menunjukkan bahwa rata-rata skor dukungan keluarga pada pasien pasca 
stroke adalah $70,63 \pm 2,483$. Skor tertinggi dukungan keluarga adalah 75 dan skor terendah 64. Pada confidence interval $95 \%$ diyakini bahwa rata-rata skor dukungan keluarga pada pasien pasca stroke adalah antara 69,65 sampai dengan 71,61 .

Dukungan keluarga adalah sesuatu yang penting bagi individu yang membutuhkan sehingga individu tersebut memahami dan tahu bahwa dirinya diperhatikan. Dukungan keluarga sendiri meliputi dukungan instrumental, dukungan informasional, dukungan penilaian (Appraisal) dan yang terakhir adalah dukungan emosional ${ }^{10}$.

Keluarga merupakan orang terdekat yang selalu berinteraksi dengan pasien pasca stroke sehingga peranan keluarga sangat penting dalam upaya memberikan berbagai dukungan untuk menciptakan rasa aman bagi pasien. Pada penelitian ini, skor tertinggi yang mungkin didapatkan pada variabel dukungan keluarga adalah 96 dan pada hasil penelitian skor ratarata dukungan keluarga pada pasien pasca stroke adalah $70,63 \pm 2,483$ atau setara dengan nilai tengah, hal ini menggambarkan bahwa dukungan yang diberikan keluarga terhadap pasien pasca stroke tergolong tinggi dengan demikian maka dukungan tersebut diharapkan mampu memberikan kontribusi bagi kualitas hidup pasien pasca stroke.

\section{Distribusi Frekuensi Kualitas Hidup Pasien Pasca Stroke}

Hasil penelitian yang menunjukkan bahwa ratarata skor kualitas hidup pasien pasca stroke adalah $120,04 \pm 4,328$. Skor tertinggi kualitas hidup pasien pasca stroke adalah 127 dan skor terendah 110. Pada confidence interval 95\% diyakini bahwa rata-rata skor kualitas hidup pasien pasca stroke adalah antara 118,33 sampai dengan 121,75.

Kualitas hidup merupakan persepsi individu terhadap posisi mereka dalam konteks budaya dan nilai dimana mereka hidup dan dalam hubungannya dengan tujuan hidup, harapan, standar dan perhatian. Hal ini merupakan konsep yang luas yang mempengaruhi kesehatan fisik seseorang, keadaan psikologis, tingkat ketergantungan, hubungan sosial, keyakinan personal dan hubungannya dengan keinginan dimasa yang akan datang ${ }^{10}$. Beberapa problematika pasca stroke yang menjadikan kualitas hidup pasien pasca stroke rendah diantaranya adalah ketidakmampuan fungsi dasar, ketidakmampuan dalam beraktivitas sehari-hari, ketidakmampuan bersosialisasi, kemunduran fungsi kognitif dan gangguan psikologis $^{6}$.

Berdasarkan uraian di atas dapat dijelaskan bahwa rata-rata kualitas hidup pasien pasca stroke berada dibawah nilai tengah atau relatif memiliki kualitas hidup yang rendah, hal ini terjadi karena stroke merupakan salah satu penyakit yang memiliki berbagai komplikasi dan berdampak pada keterbatasan fungsional baik bersifat fisik maupun mental sehingga pasien akan memiliki tingkat ketergantungan pada orang lain yang tinggi dan seiring berjalannya waktu maka akan menurunkan keyakinan dan pandangan hidup pasien. 
Hubungan Dukungan Keluarga dengan Kualitas Hidup Pasien Pasca Stroke

Hasil uji statistik menggunakan Person Product Moment diperoleh rata-rata dukungan keluarga pada pasien pasca stroke adalah 70,63 $\pm 2,483$ dan rata-rata skor kualitas hidup adalah 120,04 $\pm 4,328$. Pada hasil uji statistik didapatkan nilai $p$-value $=0,000 \quad(p<\alpha \quad 0,05)$ yang menunjukkan ada hubungan antara dukungan keluarga dengan kualitas hidup pasien pasca stroke. Hasil korelasi Pearson didapatkan nilai sebesar 0,774 arah korelasi positif dengan kekuatan hubungan kuat, artinya semakin tinggi dukungan keluarga maka akan semakin meningkatkan kualitas hidup pasien pasien pasca stroke.

Penelitian ini sesuai dengan teori bahwa dukungan keluarga merupakan sebuah perjalanan dalam kehidupan yang memiliki sifat dan jenis dukungan sosial yang berbeda antara satu individu dengan individu lainnya. Namun demikian, dalam semua tahap siklus kehidupan, besar kecilnya dukungan yang diberikan oleh keluarga akan memberikan manfaat yang banyak termasuk dalam upaya meningkatkan kesehatan keluarga ${ }^{12}$. Terakumulasinya berbagai gejala sisa pasca stroke, baik fisik maupun psikis ini akan mengakibatkan problematika yang lebih luas. Problematika ini antara lain problematika ketidakmampuan fungsi dasar, ketidakmampuan dalam beraktifitas sehari-hari, ketidakmampuan bersosialisasi, kemunduran fungsi kognitif sampai dengan problematika psikologis. Demikian pula akibat lanjut problematika pasca stroke adalah ketidakmandirian pasien yang akan menjadikan kualitas hidup pasien pasca stroke rendah. Kualitas hidup yang menurun dapat mempengaruhi semangat hidup penderita. Oleh karena itu dukungan sosial keluarga juga berperan dalam meningkatkan kualitas hidup penderita pasca stroke ${ }^{6}$.

Hasil penelitian ini sejalan dengan penelitian sebelumnya bahwa pada analisis spearman rank dukungan keluarga yang mencakup dukungan emosional, informasi, instrumental dan penghargaan terbukti berhubungan dengan kualitas hidup pasien pasca stroke $(\mathrm{p}<0,05)^{13}$.

Berdasarkan uraian hasil penelitian di atas dapat dijelaskan bahwa dukungan keluarga terbukti memiliki korelasi positif dalam kategori kuat terhadap kualitas hidup pasien pasca stroke. Hal ini dapat terjadi karena dukungan keluarga merupakan sumber daya eksternal utama yang secara ekstensif mampu menjadi moderator stres kehidupan bagi pasien sehingga pasien merasa bahwa dirinya diperhatikan atau dicintai, dihargai serta masih menjadi bagian dari keluarga yang dibutuhkan. Oleh karena itu, jelaslah bahwa keluarga memiliki peranan penting dalam meningkatkan kualitas hidup pasien pasca stroke sehingga upaya untuk meningkatkan kualitas hidup pasien pasca stroke dapat dilakukan melalui pendekatan keluarga dimana keluarga diharapkan dapat memberikan dukungan pada pasien pasca stroke baik berbentuk dukungan instrumental, informasional, appraisal, maupun emosional. 


\section{KESIMPULAN}

Terdapat hubungan dukungan keluarga dengan kualitas hidup pasien pasca stroke $(r=0,774$; $p$-value $0,000<\alpha 0,05)$.

\section{DAFTAR PUSTAKA}

1. WHO, "Cardiovascular diseases (CVDs)," 2017. [Daring]. Tersedia pada: https://www.who.int/news-room/factsheets/detail/cardiovascular-diseases(cvds). [Diakses: 01-Jan-2019].

2. J. M. Black dan J. H. Hawks, Keperawatan Medikal Bedah: Manajemen Klinis untuk Hasil yang Diharapkan, Edisi 8., vol. 3. Singapura: Elsevier Inc, 2014.

3. Kemenkes RI, "Riset Kesehatan Dasar 2013," Badan Penelit. dan Pengemb. Kesehat. Kementeri. Kesehat. RI, no. 1, hal. 1-303, 2013.

4. F. B. Batticaca, Asuhan Keperawatan Pada Klien dengan Gangguan Sistem Persarafan. Jakarta: Salemba Medika, 2008.

5. N. Bustan, Manajemen Pengendalian Penyakit Tidak Menular. Jakarta: PT. Rineka Cipta, 2015.

6. U. B. Rahayu, "Meningkatkan Kualitas Hidup Pasca Stroke Melalui Aktivasi Otak," Surakarta, 2013.

7. C. T. Nurwahyuni, "Kualitas Hidup Pasien Pasca Stroke Berkaitan dengan Jenis Stroke dan Letak Lesi," Universitas Diponegoro, 1999.

8. D. Y. Handayani dan D. E. Dewi, "Analisis Kualitas Hidup Penderita dan Keluarga Pasca Serangan Stroke (dengan gejala sisa)," Psycho Idea, vol. 7, no. 1, hal. 35-44, 2009.

9. Dinas Kesehatan Kota Metro "Profil Kesehatan Kota Metro", 2018
10. A. E. Prasetyawati, Ilmu Kesehatan Masyarakast Untuk Kebidanan Holistik. Yogyakarta: Nuha Medika, 2011.

11. J. Bobes, M. P. G. Porilla, M. T. Bascaran, P. A. Saiz, dan M. Bousono, "Quality of life for schizophrenic patients," Dialogues Clin. Neurosclence, vol. 9, no. 2, hal. 215226, 2007.

12. N. Effendy, Dasar-dasar Keperawatan Kesehatan Masyarakat, Edisi 2. Jakarta: Buku Kedokteran EGC, 1998.

13. Rahman, F. S. T. Dewi, dan I. Setyopranoto, "Dukungan Keluarga dan Kualitas Hidup Bagi Penderita Stroke Pada Fase Pasca Akut di Kabupaten Wonogiri," BKM J. Community Med. Public Heal., vol. 33, no. 8, hal. 383-390, 2017. 